\title{
Penyisihan Polutan pada Palm Oil Mill Effluent (POME) Menggunakan Konsorsium Mikroalga-Bakteri dengan Sistem High Rate Algae Reactor (HRAR)
}

\author{
Pollutant Removal in Palm Oil Mill Effluent (POME) \\ using Microalgae-Bacterial Consortium in the \\ High Rate Algae Reactor (HRAR) System
}

\author{
Shinta Elystia ${ }^{1 *}$, Vonny Meidina Rizani ${ }^{2}$, dan Sri Rezeki Muria ${ }^{3}$ \\ ${ }^{1}$ Teknik Lingkungan, Fakultas Teknik, Universitas Riau, Jl Melati Indah Perum. Resti Graha Blok F \\ No 1, Pekanbaru, 28291. \\ ${ }^{2}$ Teknik Lingkungan, Fakultas Teknik, Universitas Riau, Jl Kembang Harapan No 17, Pekanbaru, \\ 28132. \\ ${ }^{3}$ Teknik Kimia, Fakultas Teknik, Universitas Riau, Jl Bambu Kuning No 18M, Pekanbaru, 28281.
}

*corresponding author, email: shintaelystia@yahoo.com

Manuscript received: 22-02-2021. Accepted: 04-05-2021

\begin{abstract}
ABSTRAK
Pabrik minyak sawit selain menghasilkan minyak sawit mentah juga menghasilkan produk sampingan berupa Palm Oil Mill Effluent (POME). POME mengandung bahan-bahan organik dan polutan dalam jumlah yang tinggi. Salah satu metode yang dapat diterapkan untuk mengolah POME adalah sistem High Rate Algae Reactor (HRAR). Sistem HRAR memanfaatkan konsorsium mikroalga-bakteri, sehingga memiliki kinerja yang lebih baik dalam menyisihkan polutan pada POME dan meningkatkan pertumbuhan mikroorganisme. Penelitian ini bertujuan untuk mengetahui pengaruh konsentrasi suspensi mikroalga pada sistem HRAR terhadap efisiensi penyisihan Chemical Oxygen Demand (COD) dan nitrogen total. Penelitian dilakukan secara batch pada sistem HRAR yang dilengkapi dengan paddle wheel, dengan variasi konsentrasi suspensi mikroalga yaitu $0 ; 10 ; 15 ; 20 ;$ dan 25 (\% v/v). Penelitian berlangsung selama 7 hari dan memanfaatkan matahari sebagai sumber cahaya. Berdasarkan hasil penelitian, konsentrasi suspensi mikroalga 25\% memiliki kepadatan sel mikroalga tertinggi yaitu sebesar $6,34 \times 10^{6} \mathrm{sel} / \mathrm{mL}$ dan menunjukkan efisiensi penyisihan COD dan nitrogen total terbaik, yaitu sebesar $78,79 \%$ dan $80,37 \%$.
\end{abstract}

Kata kunci : Bakteri; High Rate Algae Reactor (HRAR); Palm Oil Mill Effluent (POME); Polutan; Mikroalga

\section{ABSTRACT}

Palm oil mills in addition to producing crude palm oil also produce by-products in the form of Palm Oil Mill Effluent (POME). POME contains high amounts of organic ingredients and pollutants. One 
method that can be applied to treat POME is the High Rate Algae Reactor (HRAR) System. The HRAR system uses microalgae-bacterial consortium that has better performance in removing pollutants in POME and increasing the growth of microorganisms. This research aim by determining the effect of microalgae suspension concentration in the HRAR system towards the removal efficiency of Chemical Oxygen Demand (COD) and total nitrogen. The research was conducted in batch in the HRAR system that equipped with a paddle wheel, by variations of microalgae suspension concentration as $0 ; 10 ; 15 ; 20$; and $25(\% \mathrm{v} / \mathrm{v})$. The research was carried out for 7 days and used the sun as a source of light. Based on the research results, $25 \%$ of microalgae suspension concentration has the highest microalgae cell density, was $6,34 \times 106$ cells $/ \mathrm{mL}$ and showed the best removal efficiency of COD and total nitrogen, were $78.79 \%$ and $80.37 \%$.

Keywords : Bacterial; High Rate Algae Reactor (HRAR); Palm Oil Mill Effluent (POME); Pollutant; Microalgae

\section{PENDAHULUAN}

Pabrik minyak sawit dalam proses pengolahan Crude Palm Oil (CPO) menghasilkan produk sampingan berupa limbah cair, yang dikenal dengan Palm Oil Mill Effluent (POME). Sistem kolam terbuka yang terdiri dari kolam aerobik, kolam anaerobik, dan kolam fakultatif hingga saat ini masih dimanfaatkan untuk mengolah POME di Indonesia (Febijanto, 2010). Namun, pengolahan POME menggunakan sistem kolam terbuka memerlukan waktu detensi yang lama, lahan yang luas, serta menghasilkan gas $\mathrm{CO}_{2}$ dan metana yang dapat terlepas ke udara (Rahardjo, 2009). Menurut Yonas dkk (2012), sistem kolam terbuka tersebut mampu menurunkan kandungan BOD dan COD pada POME, namun tidak dapat memanfaatkan unsur hara seperti N, P, dan K secara optimal.

Pengolahan POME menggunakan konsorsium mikroalga-bakteri dapat menjadi suatu alternatif pengolahan yang efektif dan efisien. Menurut Kazamia dkk. (2012), penggunaan konsorsium yang terdiri dari beberapa jenis mikroalga dan bakteri berpotensi mengoptimalkan pertumbuhan kultur dalam mengolah limbah. Bakteri mendegradasi bahanbahan organik menjadi senyawa yang lebih sederhana dan menghasilkan senyawa karbon dioksida yang merupakan sumber karbon bagi mikroalga. Mikroalga memanfaatkan bahanbahan organik sederhana sebagai sumber nutrien dan menghasilkan oksigen dihasilkan melalui proses fotosintesis, kemudian dimanfaatkan kembali oleh bakteri untuk mendegradasi bahan-bahan organik (Zalfiatri dkk., 2017).

Salah satu pabrik minyak sawit di Provinsi Riau yang melakukan pengolahan POME yaitu PT. Y. Pada kolam IV PT. Y, terdapat konsorsium mikroalga-bakteri indigenous. Pemanfaatan konsorsium mikroalga-bakteri untuk menyisihkan polutan pada POME, terutama konsorsium indigenous masih belum banyak diteliti. Salah satu alternatif yang dapat meningkatkan pertumbuhan mikroalga dan bakteri adalah sistem High Rate Algae Reactor (HRAR). HRAR merupakan suatu sistem pengolahan air limbah dan pemanfaatan nutrisi berdasarkan interaksi konsorsium mikroalga-bakteri (Farahdiba dkk., 2018). Sistem HRAR memerlukan proses pengadukan (mixing) agar nutrien dan mikroorganisme tercampur merata dan menghindari terjadinya pengendapan mikroalga di dasar reaktor (Assemany, 2015). Sistem HRAR pernah dioperasikan oleh Slamet (2016) secara batch dengan kedalaman air 25 $\mathrm{cm}$ dan menggunakan pencahayaan alami, mampu menyisihkan $\mathrm{COD}$, amonia $\left(\mathrm{N}-\mathrm{NH}_{3}\right)$, dan nitrat $\left(\mathrm{NO}_{3}\right)$ menjadi 63,40; 71,30; dan 64,70\% berturut-turut. Meningkatnya konsentrasi suspensi mikroalga yang terdapat di dalam air limbah berpengaruh terhadap efisiensi penyisihan polutan pada air limbah (Zulfarina dkk., 2013).

Penelitian ini melakukan variasi konsentrasi suspensi mikroalga pada sistem HRAR, sebesar $0 ; 10 ; 15 ; 20$; dan $25 \%$ dari volume kerja. Kedalaman air limbah pada HRAR 
mengacu pada penelitian Waizh (2017), dimana pada kedalaman air $15 \mathrm{~cm}$ terjadi penyisihan BOD dan COD paling tinggi. Mixing pada HRAR dilakukan selama 24 jam dengan kecepatan $20 \mathrm{~cm} / \mathrm{dt}$. Adapun tujuan dari penelitian ini adalah mempelajari pengaruh konsentrasi suspensi mikroalga pada sistem HRAR terhadap efisiensi penyisihan COD dan Nitrogen Total pada POME.

\section{BAHAN DAN METODE}

\section{Waktu dan Tempat Percobaan}

Penelitian dilaksanakan selama 5 bulan, terhitung dari bulan Mei - September 2019 di Laboratorium Pengendalian Pencemaran Lingkungan, Fakultas Teknik, Universitas Riau. Parameter yang dianalisis dalam penelitian ini antara lain jumlah sel mikroalga, Mixed Liquor Volatile Suspended Solid (MLVSS), suhu, pH, COD, dan Nitrogen total.

\section{Prosedur}

Persiapan awal sebelum melakukan penelitian utama yaitu persiapan reaktor, mikroalga, dan POME yang akan digunakan dalam penelitian utama. Reaktor yang digunakan dalam penelitian ini yaitu High Rate Algae Reactor (HRAR) yang berjumlah 5 unit. HRAR dilengkapi paddle wheel berkecepatan $20 \mathrm{~cm} / \mathrm{dt}$ dan diberi sekat ditengah reaktor. Desain untuk setiap reaktor sama, yaitu $40 \mathrm{~cm}$ x $25 \mathrm{~cm}$ x $30 \mathrm{~cm}$, dengan volume kerja sebesar $15 \mathrm{~L}$. Pencahayaan pada reaktor menggunakan pencahayaan yang bersumber dari cahaya matahari. Desain HRAR dapat dilihat pada Gambar 1.

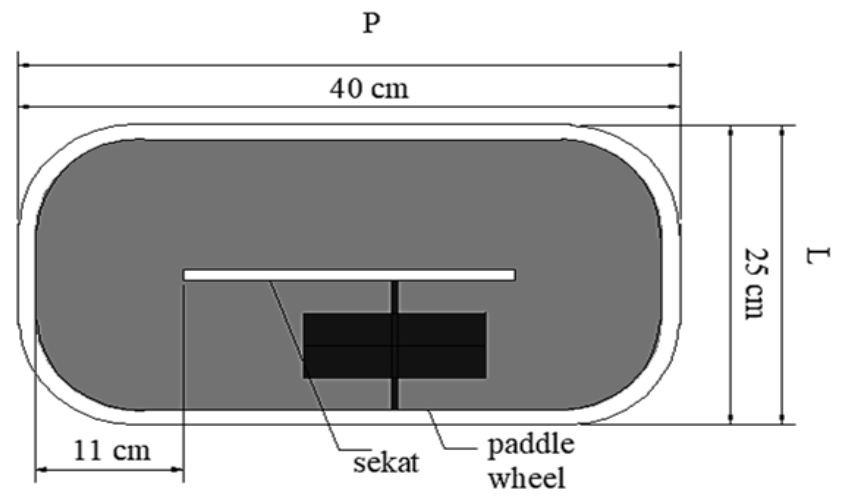

(a)

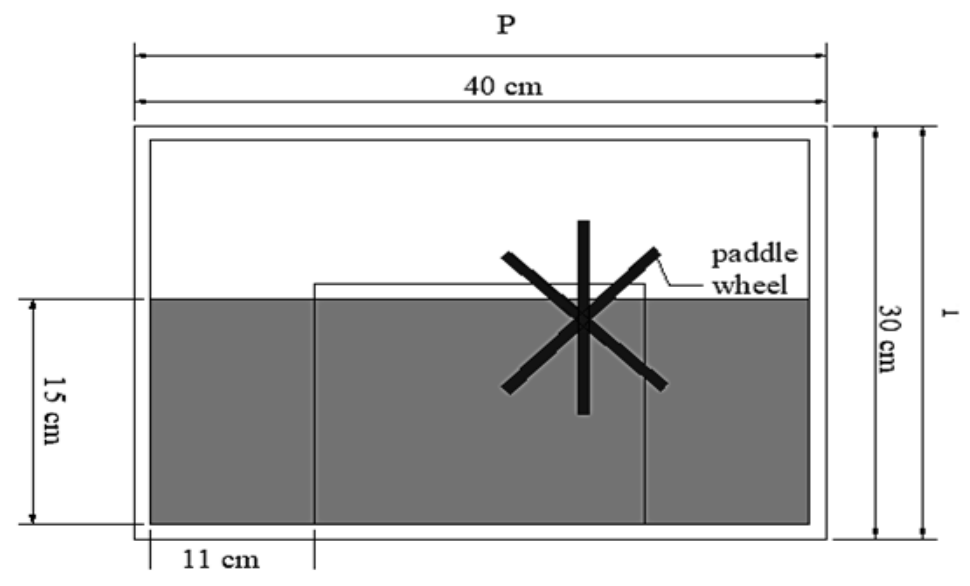

(b)

Gambar 1. Desain HRAR (a) Tampak Atas dan (b) Tampak Samping 
Penelitian ini memerlukan suspensi mikroalga sebanyak 10,5 L. Mikroalga diambil dari kolam ke IV PT. Y menggunakan plankton net berukuran 30-50 $\mu$ untuk menyaring fitoplankton. Mikroalga dikultivasi hingga mencapai kepadatan sel minimal $10^{6} \mathrm{sel} / \mathrm{mL}$ agar mikroalga dapat digunakan dalam percobaan utama. Kultivasi dilakukan selama 2 minggu dengan membiakkan sebanyak $400 \mathrm{ml}$ suspensi mikroalga ke dalam medium yang terdiri dari $230 \mathrm{ml}$ Bold Bassal Medium (BBM) dan $3370 \mathrm{ml}$ POME serta diberi aerasi. Pembiakan kultur dilakukan dengan memanfaatkan sinar matahari sebagai sumber cahaya dan penggunaan aerasi selama 24 jam untuk menjaga kadar oksigen terlarut di dalam air limbah.

Palm Oil Mill Effluent (POME) yang digunakan pada penelitian ini yaitu influent dari kolam ke IV (empat) PT. Y dan diperlukan POME sebanyak 65 L. Metode pengambilan sampel dilakukan secara gabungan waktu. Air limbah kemudian disaring untuk menyisihkan partikel dan pasir yang berukuran besar. Setelah disaring, dilakukan pengukuran $\mathrm{pH}$ dan suhu POME di lapangan. Selanjutnya sampel dibawa ke laboratorium untuk dilakukan uji COD dan N-total awal.

Penelitian utama menggunakan HRAR yang dioperasikan secara batch selama 7 hari. Penelitian ini melakukan variasi konsentrasi suspensi alga, yaitu $0 ; 10 ; 15 ; 20$; dan 25 (\% v/v). Pencahayaan dilakukan secara alami menggunakan sinar matahari. Setiap reaktor dilengkapi paddle wheel dengan kecepatan $20 \mathrm{~cm} / \mathrm{dt}$. Mixing dilakukan secara kontinu selama 24 jam untuk menghindari pengendapan mikroalga dan mengontakkan mikroalga dengan nutrien.

\section{Analisis Data}

Parameter yang dianalisis pada penelitian ini yaitu jumlah sel mikroalga, suhu, dan $\mathrm{pH}$, MLVSS, COD, dan N-Total. Jumlah sel mikroalga, $\mathrm{pH}$, dan suhu diukur setiap hari, sedangkan MLVSS, COD, dan N-total dianalisis pada hari ke 0, 1, 3, 5, dan 7. Hal ini dilakukan untuk mengetahui kemampuan konsorsium mikroalga-bakteri dalam memanfaatkan bahan-bahan organik dalam POME sebagai nutrisi. Data hasil pengukuran jumlah sel mikroalga, $\mathrm{pH}$, suhu, MLVSS, COD, dan N-Total diplotkan ke dalam bentuk grafik dengan hubungan waktu (hari) dalam bentuk logaritmik.

Tabel 1. Metode Analisis Penelitian

\begin{tabular}{cc}
\hline Analisis & Metode / Alat \\
\hline Jumlah Sel Alga & Thomacytometer \\
MLVSS & Standard Method 2540 E \\
$\mathrm{pH}$ & SNI 06-6989.11-2004 \\
Suhu & SNI 06-6989.23-2005 \\
COD & SNI 6989.73-2009 \\
N-Total & SNI 4146-2013 \\
\hline
\end{tabular}

Efisiensi penyisihan dapat diketahui menggunakan persamaan :

Efisiensi $(\%)=\frac{C_{\text {in }}-C_{\text {ef }}}{C_{\text {in }}} \times 100 \%$

Keterangan:

$\mathrm{C}_{\mathrm{in}}=$ Konsentrasi influen $(\mathrm{mg} / \mathrm{L})$

$\mathrm{C}_{\mathrm{ef}}=$ konsentrasi efluen $(\mathrm{mg} / \mathrm{L})$ 


\section{Jumlah Sel Mikroalga}

\section{HASIL DAN PEMBAHASAN}

Penelitian ini melakukan variasi konsentrasi suspensi mikroalga sebesar 0 (kontrol); 10; 15; 20; dan 25\% dari volume kerja. Selama proses pengolahan POME pada penelitian ini, jumlah sel mikroalga yang hidup dihitung setiap 24 jam menggunakan thomasitometer dan mikroskop. Penghitungan jumlah sel bertujuan untuk melihat pengaruh dari variasi konsentrasi suspensi mikroalga terhadap jumlah sel mikroalga dan memastikan bahwa mikroalga mampu tumbuh dengan baik. Pengamatan sel mikroalga menggunakan mikroskop dapat dilihat pada Gambar 2.

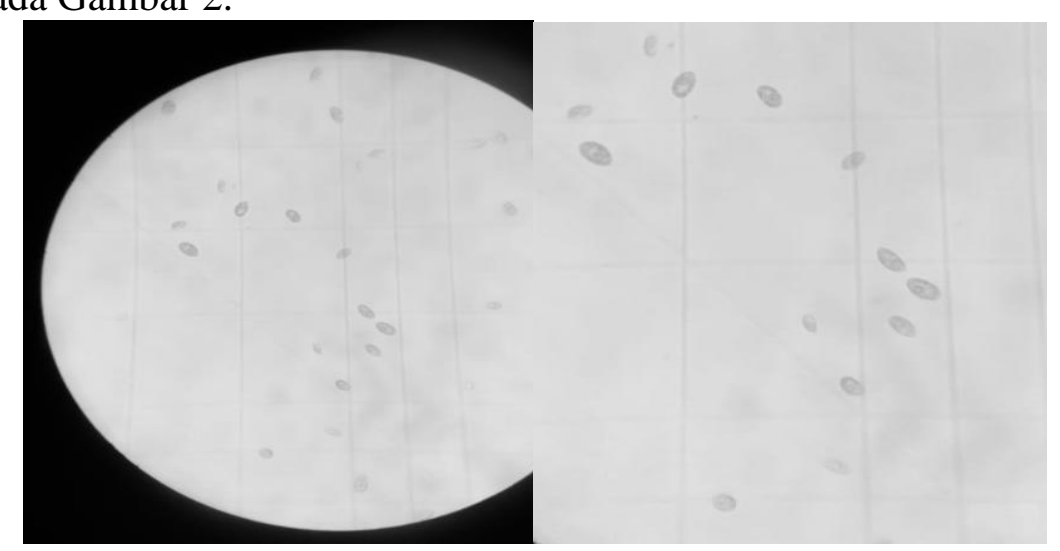

Gambar 2. Pengamatan Sel Mikroalga Menggunakan Mikroskop

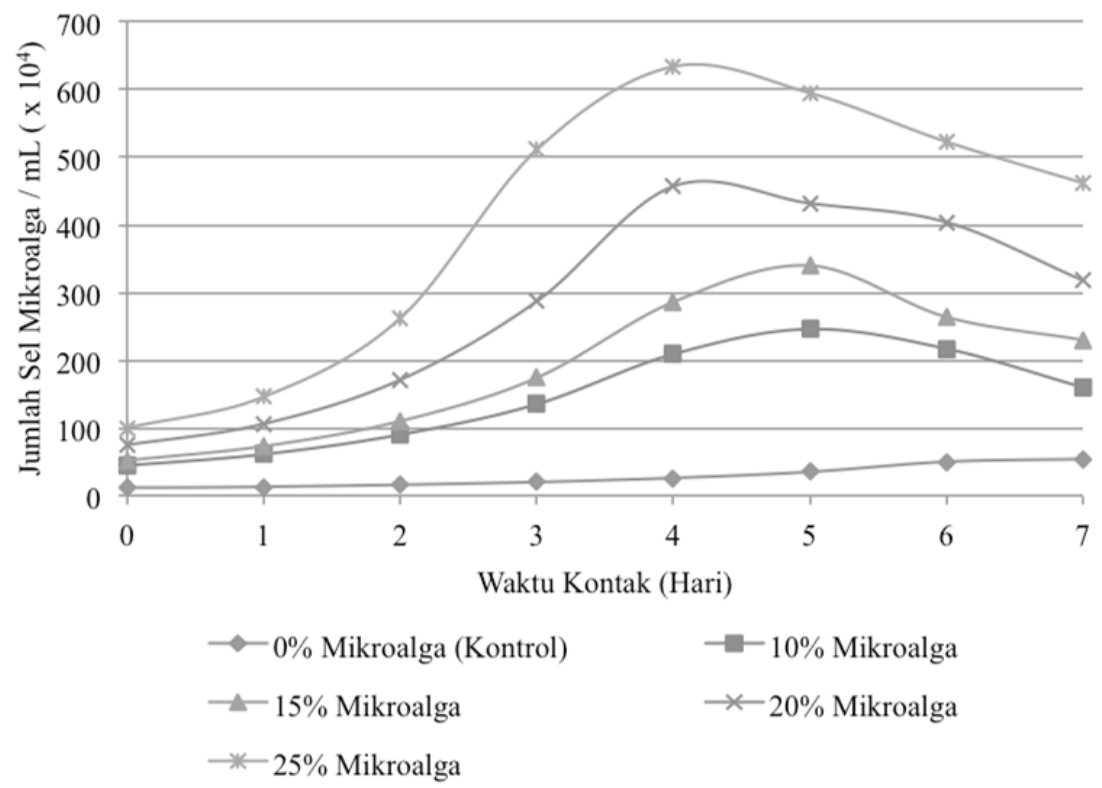

Gambar 3. Grafik Hubungan Konsentrasi Suspensi Mikroalga terhadap Jumlah Sel Mikroalga

Kepadatan suspensi mikroalga awal yang ditambahkan ke dalam setiap reaktor yaitu sebesar 2,08 x $10^{6} \mathrm{sel} / \mathrm{mL}$. Menurut Hadiyanto (2013), pada awal kultivasi, kepadatan suspensi mikroalga yang ditambahkan ke dalam medium limbah cair umumnya akan mengalami proses pengenceran terhadap medium limbah, sehingga kepadatan sel akan menurun dari kepadatan awal. Kepadatan sel mikroalga di dalam sistem HRAR yaitu 1,1; 4,4; 5,2; 7,4; dan 10 (x $10^{5} \mathrm{sel} / \mathrm{ml}$ ) berturut-turut. Mikroalga memasuki fase eksponensial sejak hari ke-2 penelitian. Pada fase ini mikroalga juga mampu menyerap nutrisi pada medium 
limbah secara optimal, sehingga kepadatan sel meningkat dan nutrisi pada medium menjadi berkurang (Prayitno, 2016). Mikroalga kemudian mengalami penurunan laju pertumbuhan.

Konsentrasi POME yang terlalu tinggi menjadi salah satu faktor penyebab menurunnya pertumbuhan sel mikroalga. Habib dkk., (2003) menginformasikan bahwa POME dengan konsentrasi yang terlalu tinggi dapat mempengaruhi warna air limbah menjadi lebih gelap, sehingga sulit untuk ditembus oleh cahaya. Minimnya pencahayaan mengakibatkan proses fotosintesis terganggu dan pertumbuhan sel mikroalga menjadi tidak optimal. Hal ini didukung oleh penelitian Can dkk., (2015) yang menguraikan bahwa pertumbuhan mikroalga paling rendah terjadi pada konsentrasi limbah $100 \%(\mathrm{v} / \mathrm{v})$ tanpa adanya pengenceran limbah. Selain itu, POME dengan konsentrasi yang terlalu tinggi juga dapat menghambat pertumbuhan mikroalga karena mengandung nutrien dalam jumlah yang terlalu tinggi.

Mixing pada sistem HRAR juga memiliki peran penting terhadap pertumbuhan sel mikroalga. Mixing berfungsi untuk meningkatkan paparan matahari terhadap sel mikroalga, mengontakkan mikroalga dengan limbah, mencegah terjadinya pengendapan mikroalga, dan sebagai pencampur udara agar lebih cepat terdifusi ke dalam medium. Menurut Chen dkk., (2016), semakin tinggi kecepatan pengadukan maka pertumbuhan mikroalga akan semakin rendah. Kecepatan yang tinggi diketahui dapat merusak struktur sel mikroalga dan membatasi waktu kontak antara mikroalga dengan limbah. Namun, kecepatan yang rendah berpotensi menyebabkan mikroalga terakumulasi di area dengan aliran yang rendah (Hadiyanto dkk., 2013). Oleh karena itu, perlu diteliti lebih lanjut mengenai pengaruh kecepatan pengadukan pada sistem HRAR.

Fase stasioner mulai terjadi pada hari ke-4 penelitian untuk konsentrasi suspensi mikroalga $20 \%$ dan $25 \%$, dan hari ke-5 untuk konsentrasi suspensi mikroalga $10 \%$ dan $15 \%$. Namun pada HRAR kontrol, mikroalga belum memasuki fase stasioner hingga hari ke-7. Hal ini dikarenakan konsentrasi POME pada HRAR kontrol yang sangat pekat, sehingga proses fotosintesis mikroalga terganggu dan memperlambat pertumbuhan mikroalga. Fase stasioner adalah fase di mana tidak ada lagi pertumbuhan mikroba, atau kecepatan pertumbuhan menjadi nol. Jumlah sel mikroba yang hidup sama dengan jumlah sel yang mati. Secara umum dalam sistem batch, sel-sel mikroalga memasuki fase stasioner pada hari ke-5 hingga hari ke-10 (Prayitno, 2016).

Jumlah sel mikroalga tertinggi dengan variasi konsentrasi suspensi mikroalga 0\%; $10 \%$; $15 \%$; 20\%; dan 25\% yaitu sebanyak 0,$54 ; 2,46 ; 3,40 ; 4,57$; dan 6,34 ( x $10^{6}$ ) berturutturut. Perlakuan konsentrasi suspensi mikroalga 25\% menunjukkan jumlah sel mikroalga yang paling banyak. Hariz dan Takriff (2017) menyatakan bahwa konsentrasi suspensi mikroalga yang lebih tinggi akan mempengaruhi fase eksponensial pertumbuhan mikroalga. Seiring dengan meningkatnya konsentrasi suspensi mikroalga, maka fase eksponensial mikroalga dapat dicapai lebih cepat, sehingga proses pengolahan limbah dapat berlangsung dengan cepat.

\section{Suhu Medium Kultivasi}

Suhu lingkungan memiliki pengaruh yang signifikan terhadap produktivitas mikroalga dan efisiensi penyisihan nutrien di dalam air limbah. Suhu optimal untuk pertumbuhan mikroalga dalam suatu medium bervariasi, tergantung spesies mikrolaga dan aklimatisasinya terhadap lingkungan tertentu. Secara umum, mikroalga mampu bertahan hidup pada suhu $10^{\circ} \mathrm{C}-35^{\circ} \mathrm{C}$ (Singh dan Singh, 2015). Pada suhu dibawah $16^{\circ} \mathrm{C}$, mikroalga masih dapat tumbuh dalam keadaan lambat, dan pada suhu diatas $35^{\circ} \mathrm{C}$, beberapa mikroalga dapat mati atau lisis (Hadiyanto dan Azim, 2012). Hasil pengukuran suhu pada setiap HRAR selama proses kultivasi mikroalga pada medium POME dapat dilihat pada Gambar 4. 


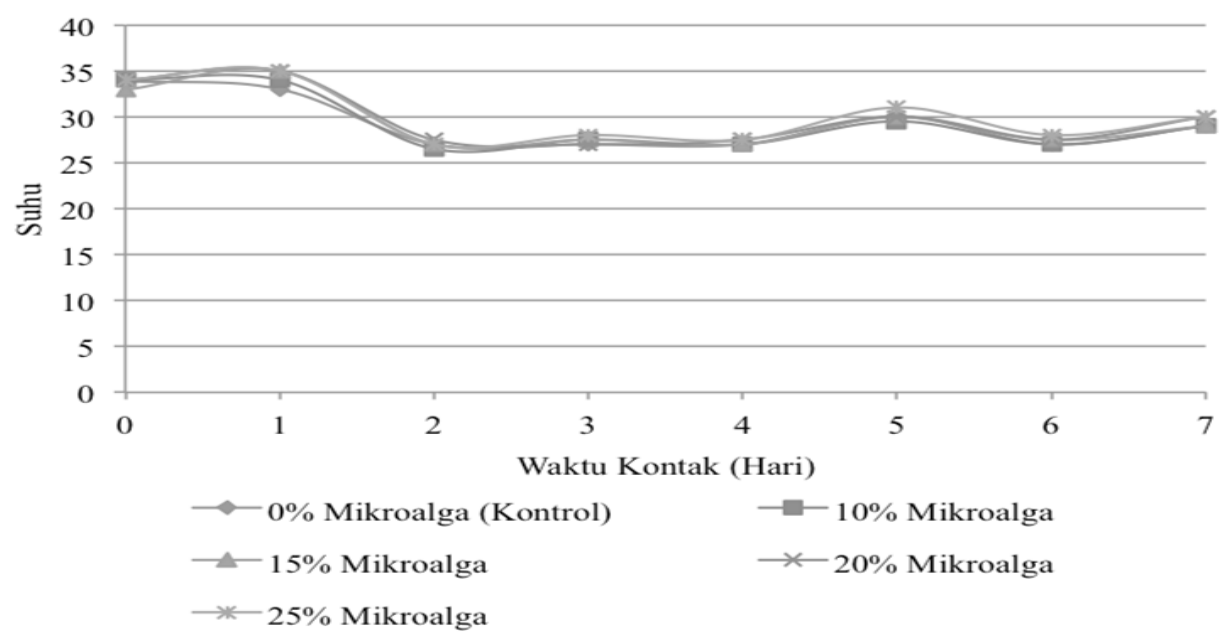

Gambar 4. Grafik Hubungan Konsentrasi Suspensi Mikroalga terhadap Suhu Medium

Dari hasil penelitian, dapat dilihat bahwa suhu pada setiap HRAR berkisar antara $27^{\circ} \mathrm{C}-35^{\circ} \mathrm{C}$ dan berada pada rentang suhu yang optimal bagi pertumbuhan mikroalga. Park dkk., (2011) menyatakan bahwa suhu optimal untuk pertumbuhan mikroalga berada pada rentang $25^{\circ} \mathrm{C}-35^{\circ} \mathrm{C}$. Fluktuasi suhu pada HRAR selama penelitian dipengaruhi oleh kondisi cuaca dan radiasi matahari. Selain itu, meningkatnya konsentrasi suspensi mikroalga pada HRAR yang berbeda dapat menyebabkan terjadinya efek internal shading, sehingga terjadi perbedaan intensitas cahaya matahari yang diterima dan menyebabkan suhu pada medium menjadi lebih rendah.

\section{pH Medium Kultivasi}

Derajat keasaman $(\mathrm{pH})$ adalah parameter yang menyatakan tingkat keasaman atau kebasaan yang dimiliki oleh suatu larutan. Pemantauan nilai $\mathrm{pH}$ medium dilakukan selama proses kultivasi mikroalga guna menganalisis kinerja proses fotosintesis. Park dkk., (2011) menyatakan bahwa nilai $\mathrm{pH}$ yang optimum akan mempengaruhi kemampuan penyerapan unsur hara oleh mikroalga. Nilai $\mathrm{pH}$ juga mempengaruhi proses biokimia yang berhubungan dengan pertumbuhan dan metabolisme mikroalga. Secara umum mikroalga umumnya akan tumbuh dan berkembang dengan baik pada kondisi $\mathrm{pH}$ netral dan cenderung basa (Reynold, 2006). Hasil pengukuran $\mathrm{pH}$ selama proses pengolahan menggunakan sistem HRAR dapat dilihat pada Gambar 5.

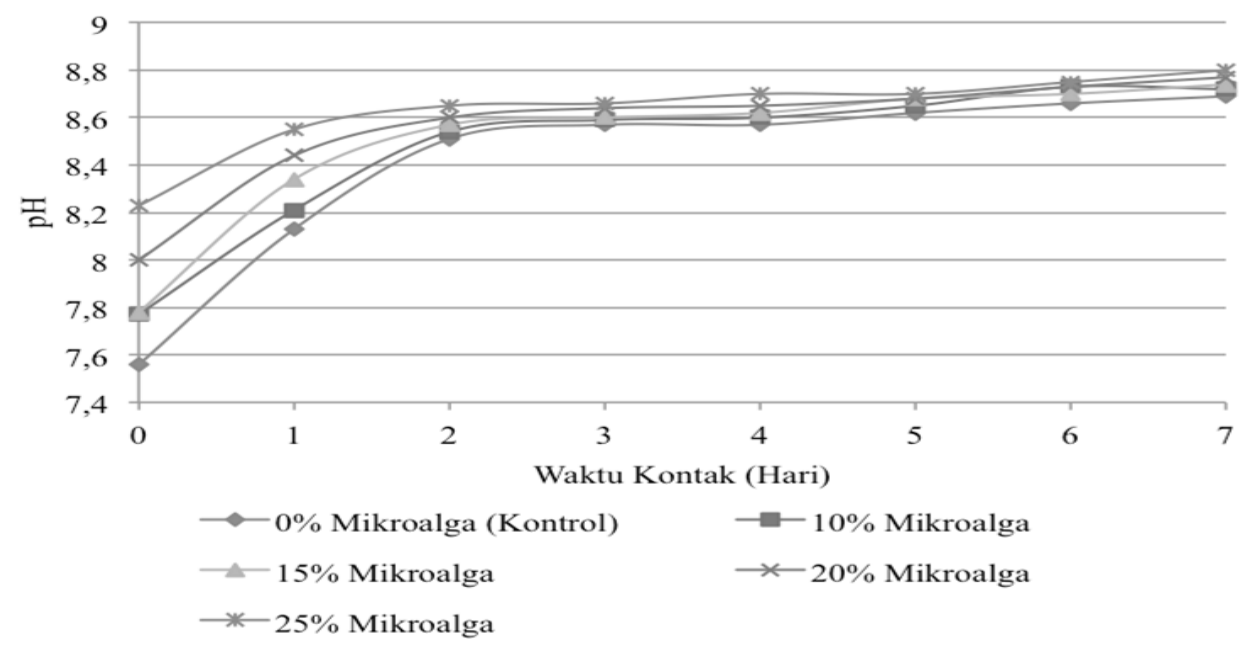

Gambar 5. Grafik Hubungan Konsentrasi Suspensi Mikroalga terhadap pH Medium 
Nilai $\mathrm{pH}$ awal yang diperoleh dari hasil pengukuran berkisar antara 7,56-8,23. Dari hasil penelitian, dapat dilihat seluruh perlakuan pada sistem HRAR mengalami peningkatan nilai $\mathrm{pH}$ selama proses pengolahan POME. Nilai $\mathrm{pH}$ selama proses pengolahan menggunakan sistem HRAR ini berkisar antara 7,56-8,8. Kumar dkk., (2010) menyatakan nilai pH optimum untuk pertumbuhan mikroalga air tawar berada pada kisaran antara 7-9. Nilai pH yang netral cenderung basa tersebut merupakan kondisi optimum bagi mikroalga, sehingga penyerapan nutrien pada POME menjadi lebih optimal.

Peningkatan nilai $\mathrm{pH}$ sejalan dengan peningkatan kepadatan mikroalga, dimana aktivitas metabolisme meningkat seiring dengan meningkatnya kepadatan mikroalga. Mikroalga memanfaatkan karbondioksida $\left(\mathrm{CO}_{2}\right)$ sebagai sumber karbon utama dalam proses fotosintesis. Hal ini menyebabkan konsentrasi $\mathrm{CO}_{2}$ menurun dan $\mathrm{pH}$ medium meningkat hingga kisaran 8-9. Pada kondisi ini, mikroalga memanfaatkan bikarbonat $\left(\mathrm{HCO}_{3}^{-}\right)$dan karbonat $\left(\mathrm{CO}_{3}{ }^{-}\right)$sebagai sumber karbon. Reaksi kimia pada $\mathrm{HCO}_{3}{ }^{-}$dan $\mathrm{CO}_{3}{ }^{-}$yang terdisosiasi mendukung konsumsi $\mathrm{CO}_{2}$ yang kontiniu, sehingga $\mathrm{OH}^{-}$terakumulasi dan menyebabkan $\mathrm{pH}$ meningkat (Zulfarina dkk., 2013). Peningkatan pH medium juga dapat disebabkan oleh adanya peningkatan konsentrasi ammonium $\left(\mathrm{NH}_{4}^{+}\right)$akibat proses penguraian senyawa nitrogen organik. Ammonia $\left(\mathrm{NH}_{3}\right)$ larut di dalam air membentuk ammonium hidroksida $\left(\mathrm{NH}_{4} \mathrm{OH}\right)$, kemudian ammonium hidroksida terdisosiasi dan menghasilkan ammonium $\left(\mathrm{NH}_{4}^{+}\right)$.

\section{Mixed Liquor Volatile Suspended Solid (MLVSS)}

Analisis MLVSS bertujuan untuk mengetahui konsentrasi mikroorganisme di dalam air limbah. Nilai MLVSS (Mixed Liquor Volatile Suspended Solid) bergantung pada jumlah mikroorganisme, baik mikroorganisme yang hidup, mati, dan hancuran sel pada suatu sistem pengolahan air buangan menguap saat dipanaskan pada suhu $550^{\circ} \mathrm{C}$ (Slamet, 2016). Kadar MLVSS pada sistem HRAR meningkat seiring dengan meningkatnya konsentrasi suspensi mikroalga pada konsorsium mikroalga-bakteri. Penggunaan konsorsium mikroalga-bakteri dalam pengolahan limbah mampu mengoptimalkan pertumbuhan kultur (Kazamia dkk., 2012). Konsentrasi suspensi mikroalga yang besar mampu meningkatkan suplai oksigen bagi bakteri melalui mekanisme fotosintesis mikroalga. Bakteri selanjutnya memanfaatkan oksigen yang dihasilkan oleh mikroalga untuk membentuk sel-sel baru dan menguraikan bahan-bahan organik yang terdapat pada limbah (Zulfarina dkk., 2013).

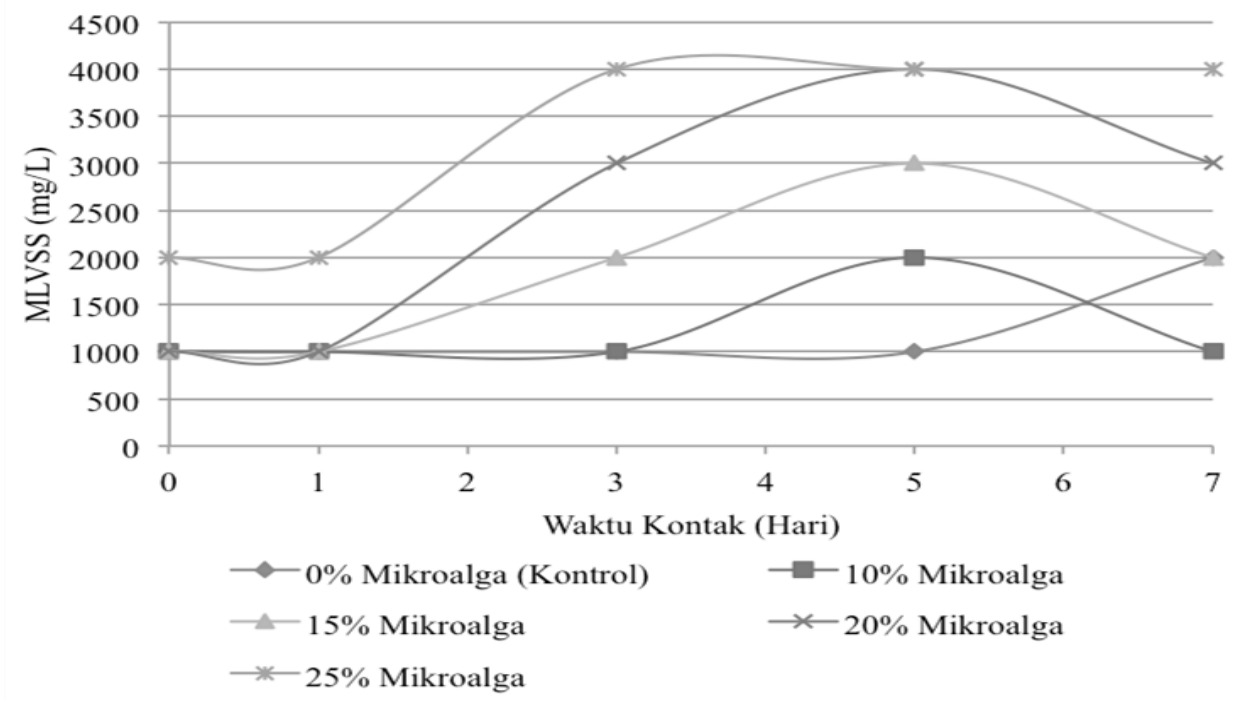

Gambar 6. Nilai MLVSS selama Proses Pengolahan 
Gambar 6 menunjukkan nilai MLVSS pada setiap HRAR, dimana nilai MLVSS mengalami fluktuasi selama penelitian berlangsung. selama penelitian berlangsung. Nilai MLVSS pada penelitian ini berkisar antara 1000-4000 mg/L. Pertumbuhan mikroalga mempengaruhi pertumbuhan bakteri di dalam sistem HRAR. Hal ini ditandai dengan nilai MLVSS yang mengalami peningkatan seiring dengan meningkatnya pertumbuhan mikroalga. Banyaknya mikroalga yang terdapat pada sistem HRAR mampu meningkatkan suplai oksigen, sehingga mampu meningkatkan kehidupan bakteri (Puspitasari dkk, 2014). Nilai MLVSS pada setiap HRAR kemudian menjadi turun setelah mikroorganisme mencapai nilai maksimum pertumbuhan. Penurunan MLVSS terjadi karena mikroorganisme, baik bakteri maupun mikroalga mengalami kematian (lisis), kemudian sel yang pecah tersuspensi di dalam medium (Anggraeni dkk, 2012). Adapun nilai MLVSS pada HRAR kontrol belum mengalami penurunan dikarenakan mikroalga pada sistem HRAR kontrol belum memasuki fase kematian, sehingga bakteri masih terus tumbuh dan mengakibatkan nilai MLVSS justru meningkat dibandingkan HRAR lainnya.

\section{Efisiensi Penyisihan Chemical Oxygen Demand (COD)}

Pengujian nilai COD dilakukan selama pengolahan POME menggunakan konsorsium mikroalga-bakteri indigenous dengan variasi konsentrasi suspensi mikroalga. Nilai COD dan efisiensi penyisihan COD pada tiap perlakuan diplotkan pada Gambar 7.

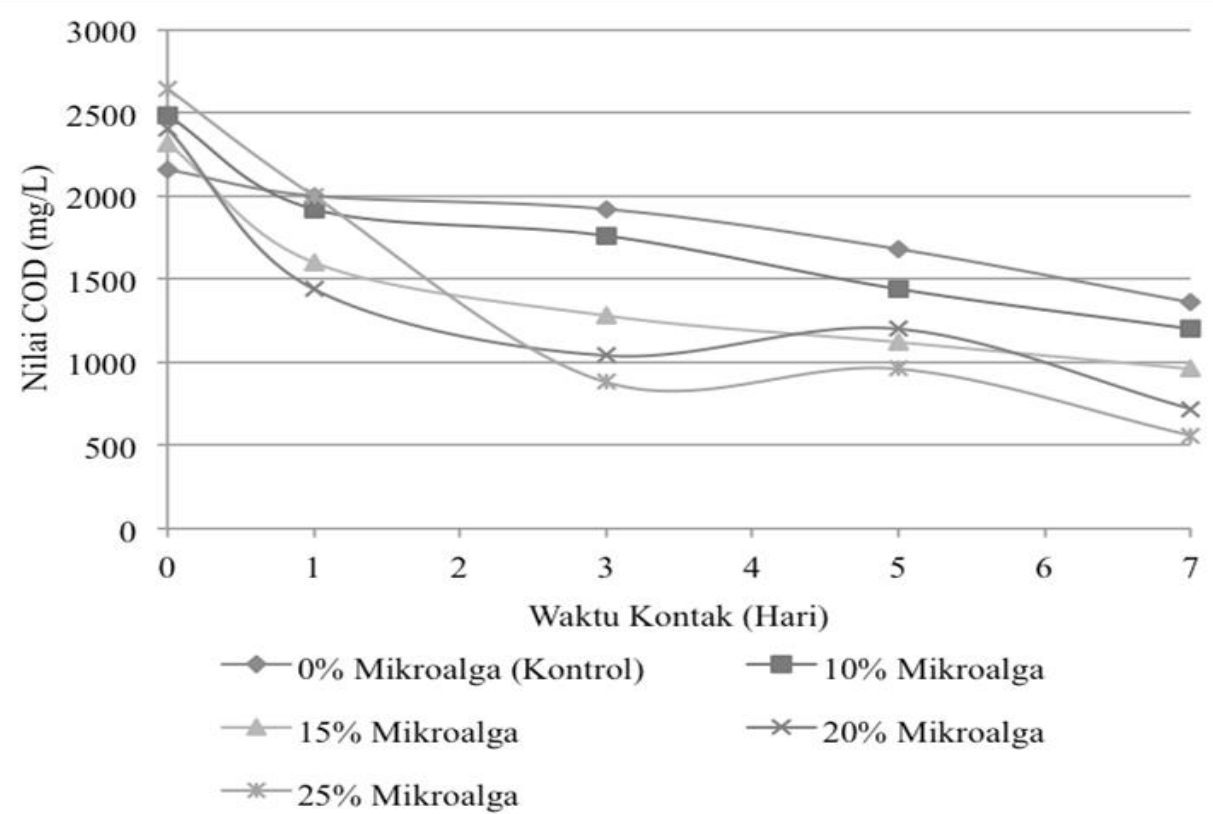

(a) 


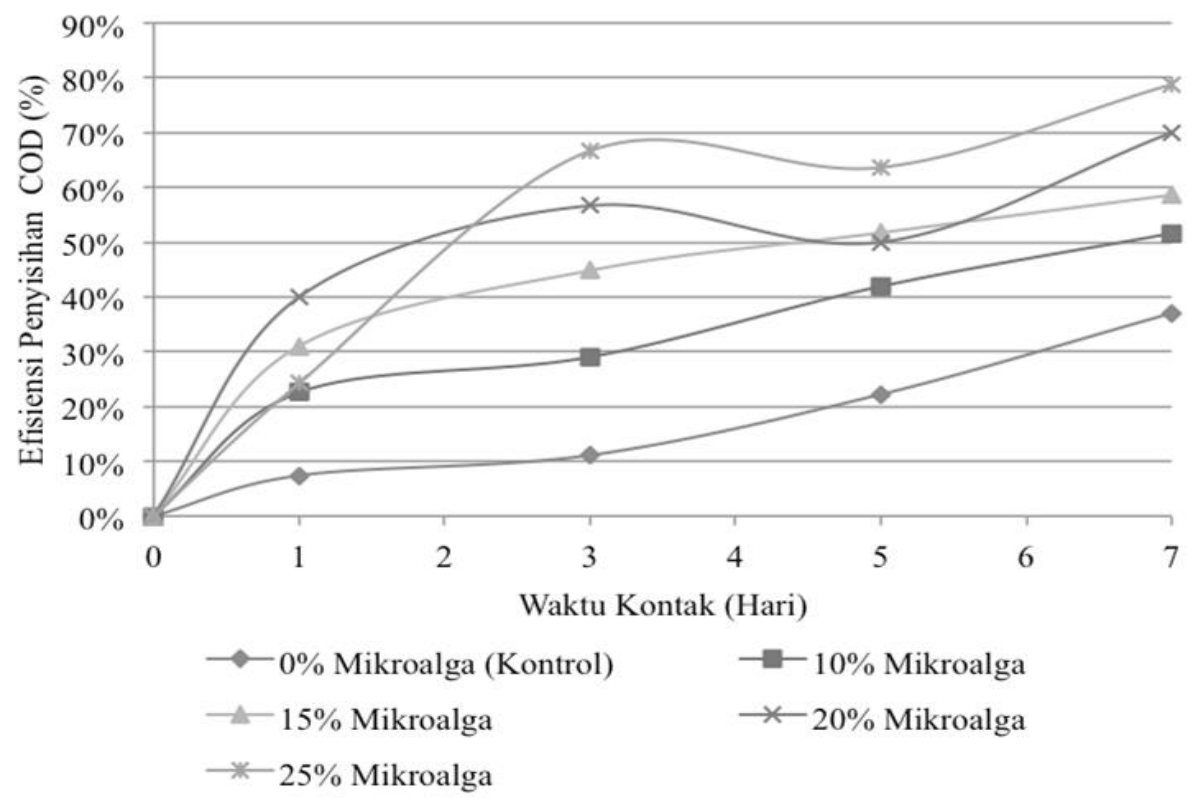

(b)

Gambar 7. Grafik (a) Nilai COD dan (b) Efisiensi Penyisihan COD

Penyisihan COD terjadi pada setiap HRAR, baik pada reaktor tanpa konsentrasi suspensi mikroalga (kontrol) maupun pada reaktor dengan variasi konsentrasi suspensi mikroalga. Adanya penyisihan COD pada reaktor kontrol sejak awal penelitian mengindikasikan terdapat bakteri indigenous pada POME yang berperan dalam menguraikan bahan-bahan organik pada limbah cair (Lau dkk., 1995). Mikroalga mampu memanfaatkan bahan-bahan organik yang telah diuraikan oleh bakteri sebagai sumber nutrien, ditandai dengan menurunnya nilai COD pada limbah (Mahdi dkk., 2012). Pemanfaatan bahan organik sebagai nutrien bagi mikroalga secara tidak langsung juga berdampak pada menurunnya angka pencemaran pada limbah cair.

Penurunan nilai COD terjadi seiring dengan bertambahnya waktu kontak. Namun, konsentrasi COD pada HRAR meningkat di pertengahan penelitian. Menurut Slamet (2016), rentang waktu hidup sistem mikroalga-bakteri berada dalam kisaran 2 hingga 6 hari. Dalam rentang waktu tersebut, sebagian mikroalga pada HRAR akan mengalami kematian (lisis). Mikroalga yang mati akan melepaskan bahan organik keluar dari selnya, dimana bahan organik akan terukur sebagai COD (Septiani dkk, 2014). Hal ini dapat menjadi penyebab naiknya nilai COD pada sistem HRAR.

Sistem HRAR pada penelitian ini memanfaatkan konsorsium mikroalga-bakteri indigenous yang berasal dari POME itu sendiri. HRAR dengan konsentrasi suspensi mikroalga yang lebih besar menunjukkan pertumbuhan mikroalga yang lebih baik dibandingkan HRAR lainnya. Konsentrasi suspensi mikroalga yang lebih besar mampu meningkatkan suplai oksigen, sehingga proses degradasi bahan organik pada limbah menjadi lebih cepat dan menurunkan nilai COD (Zulfarina dkk., 2013). Bakteri menguraikan senyawa organik pada limbah menjadi senyawa yang lebih sederhana dan menghasilkan $\mathrm{CO}_{2}$ melalui proses metabolisme (Slamet, 2016). Mikroalga menyerap bahan organik sederhana pada limbah untuk meningkatkan pertumbuhan sel-sel mikroalga. Selain itu, mikroalga memanfaatkan $\mathrm{CO}_{2}$ untuk proses fotosintesis, kemudian menghasilkan oksigen yang dimanfaatkan oleh bakteri untuk menguraikan bahan organik.

Seiring dengan meningkatnya konsentrasi suspensi mikroalga yang ditambahkan pada HRAR, maka efisiensi penyisihan COD pada penelitian akan semakin tinggi. Efisiensi 
penyisihan COD tertinggi pada penelitian ini terdapat pada sistem HRAR dengan konsentrasi suspensi mikroalga 25\%. Efisiensi penyisihan pada perlakuan ini mencapai $78,79 \%$ dan konsentrasi COD akhir $560 \mathrm{mg} / \mathrm{L}$.

\section{Efisiensi Penyisihan Nitrogen Total}

Uji nitrogen total dilakukan selama proses pengolahan POME untuk mengetahui efisiensi penyisihan nitrogen terbaik dari penelitian ini. Nilai awal nitrogen total pada HRAR dengan konsentrasi suspensi mikroalga $0 ; 10 ; 15 ; 20$; dan $25 \%$ yaitu 426,83; 433,17; 424,76; 418,66 dan 408,88 mg/l berturut-turut. Hasil analisis nilai nitrogen total dan efisiensi penyisihan pada POME selama proses pengolahan pada sistem HRAR menggunakan konsorsium mikroalga-bakteri dengan variasi konsentrasi suspensi mikroalga dapat dilihat pada Gambar 8.

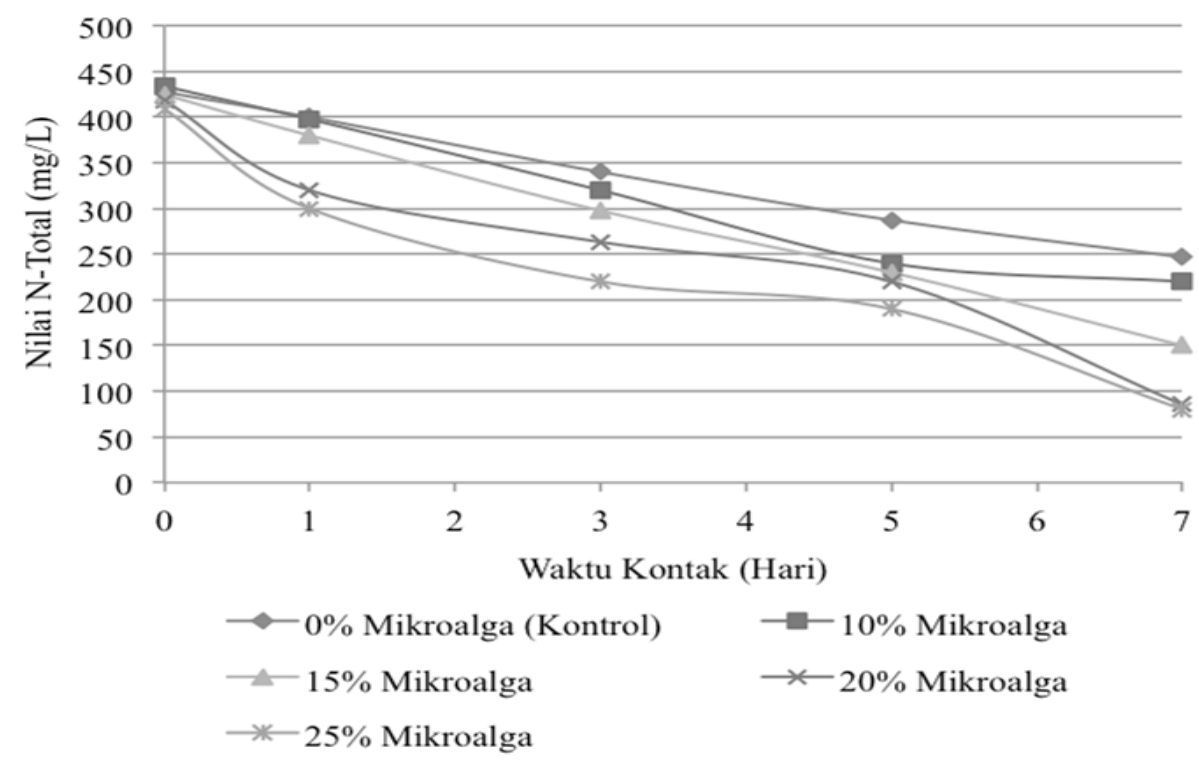

(a)

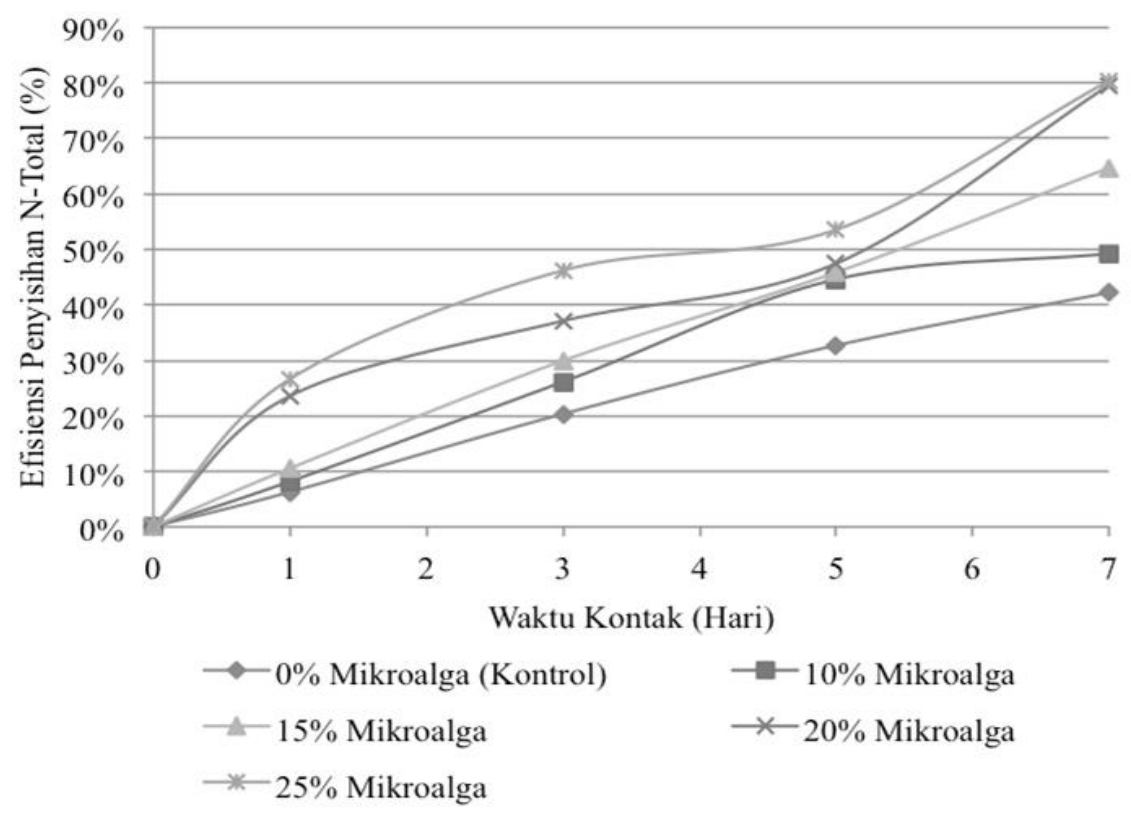

(b)

Gambar 8. Grafik (a) Nilai Konsentrasi N-Total dan (b) Efisiensi Penyisihan N-Total 
Penurunan nilai nitrogen total pada setiap HRAR terjadi seiring dengan lamanya waktu kontak. Mikroalga memanfaatkan nitrogen pada POME untuk pembentukan biomassa, dimana hal ini berdampak pada meningkatnya penyisihan nitrogen pada POME dan kandungan nutrien dalam air limbah pun berkurang. Efisiensi penyisihan nitrogen total hingga akhir penelitian untuk konsentrasi suspensi mikroalga $0 ; 10 ; 15 ; 20$; dan $25 \%$ yaitu sebesar 42,20; 49,21; 64,69; 79,61; dan 80,37\% berturut-turut.

Mekanisme utama dalam penyisihan nitrogen pada limbah yaitu asimilasi dan proses nitrifikasi-denitrifikasi. Asimilasi terjadi melalui penyerapan nitrogen oleh mikroalga dalam bentuk ion nitrat $\left(\mathrm{NO}_{3}\right)$ dan ammonium $\left(\mathrm{NH}_{4}\right)$. Menurut Slamet (2016), mikroalga cenderung menyerap ammonium terlebih dahulu, dikarenakan ammonium lebih cepat disintesa menjadi asam amino, sedangkan nitrat cenderung lebih stabil. Selain itu, proses transportasi dan asimilasi ammonium oleh sel mikroalga membutuhkan energi yang lebih sedikit dibandingkan proses transportasi dan asimilasi nitrat $\left(\mathrm{NO}_{3}\right)$.

Mekanisme transformasi bentuk senyawa nitrogen melalui proses nitrifikasidenitrifikasi juga dapat dijadikan sebagai prinsip untuk menyisihkan nitrogen yang terkandung dalam air limbah. Pada proses nitrifikasi, ammonia $\left(\mathrm{NH}_{3}\right)$ dan nitrit $\left(\mathrm{NO}_{2}\right)$ dioksidasi menjadi bentuk senyawa nitrat $\left(\mathrm{NO}_{3}\right)$ dengan kehadiran oksigen terlarut pada siang hari, kemudian diserap oleh mikroalga untuk memenuhi kebutuhan nutrisi dalam pertumbuhannya (Zulkifli dan Ami, 2001). Namun, ketika konsentrasi oksigen terlarut pada sistem HRAR berkurang, proses denitrifikasi mengambil alih proses nitrifikasi. Tahap denitrifikasi merupakan proses penyisihan nitrogen dengan mengubah senyawa nitrat menjadi gas nitrogen (Farahdiba dkk., 2018).

Efisiensi penyisihan nitrogen total terbaik pada penelitian ini terdapat pada sistem HRAR dengan konsentrasi suspensi mikroalga 25\%. Efisiensi penyisihan nitrogen total mencapai 80,37\% dengan konsentrasi nitrogen total akhir yaitu 80,28 mg/l. HRAR tanpa penambahan konsentrasi suspensi mikroalga (kontrol) juga mengalami penyisihan nitrogen, namun tidak sebesar penyisihan pada HRAR dengan penambahan konsentrasi suspensi mikroalga. Adanya penambahan konsentrasi suspensi mikroalga pada sistem HRAR mampu meningkatkan efisiensi penyisihan nitrogen pada POME dan mempersingkat waktu pengolahan limbah. Pada konsentrasi suspensi mikroalga yang lebih tinggi, jumlah sel mikroalga lebih banyak, sehingga nitrogen pada POME dapat termanfaatkan dengan baik. Hal ini diperkuat dengan data pada Gambar 8, dimana semakin tinggi konsentrasi suspensi mikroalga pada sistem HRAR, maka efisiensi penyisihan nitrogen total pun semakin meningkat.

\section{KESIMPULAN}

Efisiensi penyisihan COD dan N-total tertinggi terdapat pada High Rate Algae Reactor (HRAR) dengan konsentrasi suspensi mikroalga sebanyak 25\%, dengan efisiensi penyisihan COD dan N-total masing-masing sebesar 78,79\% dan 80,37\%. Penelitian lanjutan dengan variasi kecepatan pengadukan (mixing) diperlukan untuk mendapatkan kondisi optimum pertumbuhan konsorsium mikroalga-bakteri pada sistem HRAR.

\section{DAFTAR PUSTAKA}

Anggraeni, B.I., Slamet, A., Hermana, J., 2012. Efek Aerasi Terhadap Dominasi Mikroba dalam Sistem High Rate Algae Pond (HRAP) untuk Pengolahan Air Boezem Morokrembangan. Jurnal Teknik Lingkungan, 1-7.

Assemany, P.P, Calijuri, M.L., Couto, E.A., Souzo, M.H.B., Silva, N.C., Santiago, A.F., Castro, J.S., 2015. Algae/Bacteria Consortium in High Rate Ponds: Influence of Solar 
Radiation on the Phytoplankton Community. Ecological Engineering, 77:154-162.

Can, S.S., Demir, V., dan Can, E., 2015. Evaluating the Dilution of Municipal Wastewater on Biomass Increase, Lipid Production and Nutrient Removal by the Blue-Green Algae Spirulina plantesis (Geisler). Fresenius Environmental Bulletin, 24(3a):904-909

Chen, Z., Zhang, X, Jiang, Z, Xuehui, C., He, H., dan Zhang, X., 2016. Light/Dark Cycle of Microalgae Cells in Raceway Ponds: Effects of Paddlewheel Rotational Speeds and Baffles Installation. Bioresource Technology, 219:387-391.

Farahdiba, A.U., Putra, A.H., Yulianto, A., Setyono, M.B., dan Saputra, W.A., 2018. Performance of Algae Reactor for Nutrient and Organic Compound Removal. Internatonal Conference on Science and Technology. UGM, Yogyakarta, 7-8 Agustus 2018.

Febijanto, Irhan., 2010. Pengurangan Gas Rumah Kaca dari Limbah Cair di Pabrik Kelapa Sawit Pinang Tinggi, Jambi dengan CDM. JRL. 6(3):275-290.

Habib M.A.B., Yusoff F.M., Phang S.M., Kamarudin M.S., dan Mohamed, S., 2003. Growth and Nutritional Values of Molina micrura Fed on Chlorella vulgaris Grown in Digested Palm Oil Mill Effluent. Asian Fisheries Science, 16:107-119.

Hadiyanto dan Azim, M., 2012. Mikroalga Sumber Pangan dan Energi Masa Depan. UPT UNDIP Press, Semarang.

Hadiyanto, 2013. Valorisasi Mikroalga untuk Pengolahan Limbah Cair Kelapa Sawit dan sebagai Sumber Energi dan Pangan Alternatif. Prosiding Rekayasa Kimia dan Proses, $1-11$.

Hadiyanto, Elmore, S., Gerven, T. V., dan Stankiewicz, A., 2013. Hydrodynamic Evaluations in High Rate Algae Pond (HRAP) Design. Chemical Engineering Journal, 217:231239.

Hariz, H.B., dan Takriff, M.S., 2017. Growth and Biomass Production of Native Microalgae Chlorella sp., Chlamydomonas sp. and Scenedesmus sp. Cultivated in Palm Oil Mill Effluent (POME) at Different Cultivation Cultivation. Transaction on Science and Technology, 4:298-311.

Kazamia, E., Czesnick, H., Nguyen V., Sherwood, E., Sasso, S., dan Smith, G., 2012. Mutualistic Interaction Between Vitamin B12 Dependent Algae and Heterotrophic Bacteria Exhibit Regulation. Environmental Microbiologi, 1:1-11.

Kumar, A., Ergas, S., Yuan, X., Sahu, A., Zhang Q, Dewulf J, Malcata FX, dan van Langenhove., 2010. Sisep Enhanced $\mathrm{CO}_{2}$ Fixation and Biofuel Production via Microalgae: Recent Developments and Future șẹpidirections. Trends Biotechnol, 28:371-380.

Lau P.S., Tam N. F. Y. dan Wong Y. S., 1995. Effect of Algal Density on Nutrient Removal from Primary Settled Wastewater. Environmental Pollution. 89:59-66.

Mahdi, M.Z., Titisari, Y.N., dan Hadiyanto., 2012. Evaluasi Pertumbuhan Mikroalga dalam Medium POME: Variasi Jenis Mikroalga, Medium dan Waktu Penambahan Nutrient. Jurnal Teknologi Kimia dan Industri, 1(1):284-291.

Park, J.B.K,. Crags, R.J, dan Shilton, A.N., 2011, Wastewater Treatment High Rate Algal Ponds for Biofuel Production. Journal of Bioresource Technology, 102:35-42.

Prayitno, J., 2016. Pola Pertumbuhan dan Pemanenan Biomassa dalam Fotobioreaktor 
Mikroalga untuk Penangkapan Karbon. Jurnal Teknologi Lingkungan, 17(1):45-52.

Puspitasari, D., Slamet, A., dan Hermana, J., 2014. Efek Pencahayaan pada Sistem HRAR untuk Menurunkan Kandungan Minyak Solar dalam Air Limbah. Jurnal Teknik Pomits. 3(2):109-113.

Rahardjo, P.N., 2009. Studi Banding Teknologi Pengolahan Limbah Cair Pabrik Kelapa Sawit. Jurnal Teknik Lingkungan, 10(1):09-18.

Reynold, C.S., 2006. Ecology of Phytoplankton. Cambridge University Press, Cambridge.

Septiani, W.D., Slamet, A., dan Hermana, J., 2014. Pengaruh Konsentrasi Substrat terhadap Laju Pertumbuhan Alga dan Bakteri Heterotropik pada Sistem HRAR. Jurnal Teknik Pomits, 3(2):98-103

Singh, S.P., dan Singh, P., 2015. Effect of Temperature and Light on the Growth of Algae

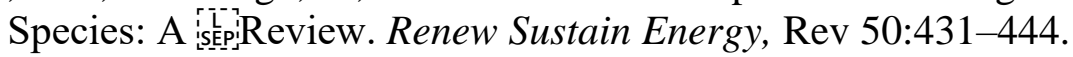

Slamet, A., 2016. Peningkatan Fungsi Boezem Morokrembangan Sebagai Pengolah Air Limbah Perkotaan Menggunakan Sistem Alga-Bakteri. Disertasi, Bidang Keahlian Teknik Lingkungan, Institut Teknologi Sepuluh Nopember, Surabaya.

Waizh, N. T., 2017. Pengaruh Densitas Alga Dan Kedalaman Reaktor Terhadap Penurunan BOD dan COD Limbah Cair Domestik. Jurnal Teknik Lingkungan, 1-12.

Yonas, R., Irzandi, U., dan Satriadi, H., 2012. Pengolahan Limbah POME (Palm Oil Mill Effluent) dengan Menggunakan Mikroalga. Jurnal Teknologi Kimia dan Industri, $1(1): 7-13$.

Zalfiatri, Y., Restuhadi, F., Maulana, T., 2017. Pemanfaatan Simbiosis Mikroorganisme BDECO3 dan Mikroalga Chlorella sp. untuk Menurunkan Pencemaran Limbah Cair Pabrik Kelapa Sawit. Dinamika Lingkungan Indonesia, 4(1):8-17.

Zulfarina, S., Irda, dan Putri, H.T., 2013. Potential Utilization of Algae Chlorella pyrenoidosa For Rubber Waste Management. Prosiding Semirata FMIPA Universitas Lampung, 1-10.

Zulkifli dan Ami, A., 2001. Pengolahan Limbah Cair Pabrik Tahu dengan Rotating

Biological Contactor (RBC) pada Skala Laboratorium. Limnotek, 8(1)21-34 